\title{
DERAJAT KESEHATAN MASYARAKAT DI PULAU LIPANG KECAMATAN KENDAHE KABUPATEN KEPULAUAN SANGIHE
}

\author{
DETERMINANT OF PUBLIC HEALTH IN LIPANG ISLAND \\ IN KENDAHE DISTRIC, SANGIHE
}

\author{
Yeanneke Tinungki, Mareike Patras, Ferdinand Gansalangi \\ Keperawatan, Politeknik Negeri Nusa Utara \\ Email:yeanneketinungki82@gmail.com
}

\begin{abstract}
Abstrak: Derajat kesehatan masyarakat di Pulau Lipang sangat penting diketahui dalam rangka penyusunan dan implementasi program kesehatan yang tepat dan berkelanjutan. Gambaran derajat kesehatan masyarakat yang optimal dapat dilihat dengan menggunakan indicator kualitas utama yakni Indeks Mortalitas, Indeks Morbiditas dan Indeks Fertilitas. Selain itu, perlu juga diperhatikan factorfaktor yang mempengaruhi kesehatan seperti; indikator kesehatan lingkungan, upaya pelayanan kesehatan dan perilaku kesehatan. Penelitian ini menggunakan rancangan deskritif dengan metode survey, populasi dalam penelitian ini yaitu seluruh Kepala Keluarga di Pulau Lipang berjumlah 106 Kepala Keluarga. Sampel dalam penelitian ini menggunakan Total sampling dan memenuhi kriteria inklusi berjumlah 77 orang. Hasil penelitian menunjukkan bahwa Indeks Mortalitas dalam 1 tahun terakhir tercatat 14 kasus kematian per 1000 penduduk. Indeks Morbiditas Penyakit Menular berjumlah 49 kasus per 1.000 penduduk, Indeks Morbiditas Penyakit Tidak Menular (PTM) berjumlah 79 kasus per 1.000 penduduk. Indeks fertilitas menunjukkan bahwa persentase ibu hamil berjumlah 7 orang atau $8 \%$ dan persentase anak balita adalah 18 orang atau $17 \%$. Faktor status gizi yakni Bayi yang tidak diberi ASI 31\%, pemberian Imunisasi BCG dan Hepatitis 0\%, menggunakan kontrasepsi $56 \%$. Indikator kesehatan lingkungan menggunakan air hujan untuk masak dan minum 100\%, upaya pelayanan kesehatan; menggunakan fasilitas yankes $94 \%$, penyuluhan kesehatan oleh nakes $74 \%$. Perilaku kesehatan; BABS di hutan 9\% dan pantai 5\%. Merokok dalam keluarga 31\% dan minum alcohol 91\%. Kesimpulan Penelitian ini menunjukkan bahwa indicator mortalitas Diabetes Melitus per-1000 penduduk adalah $40 \%$, indicator morbiditas malaria per-1000 penduduk adalah $77,78 \%$, indicator morbiditas penyakit jantung adalah 31,03\%. Indeks Fertilitas ibu hamil 8\% dan Balita $17 \%$.
\end{abstract}

Kata kunci: Derajat kesehatan Masyarakat

\begin{abstract}
Abtract: Determinat of public health in Lipang island very important to know in preparation and implementation program of health that appropriate and sustainable. Description determinant of public health is the best can be seen use indicator of main quality that is Mortality Index, Morbidity Index, and Fertility Index. Beside of these third factors very need pay attention too the other factors that influence of health is indicator of environment health, health service efforts and health behavior. This study used a descriptive design with survey method, population in this study was the head of family of 106 the amount. The sample in this study used total sampling and fulfill inclusion criteria of 77 people. The results showed that the mortality index or crude death rate of 14 cases death per 1000 people. Morbidity Index infectious disease showed 49 cases every 1000 people, morbidity of non infectious disease showed 79 cases every 1000 people. Fertility Index showed that pregnant amount of 7 people or $8 \%$ and percentage toddler were 18 people or $17 \%$. The nutritional status was baby not breastfeeding about 31\%, immunizations of BCG and Hepatitis 0\%, used contraception $56 \%$. Indicator of Environment health used water of rain for cook and drink 100\%, health service efforts; used health service facilities $94 \%$, counseling of health by health workers $74 \%$. Health behavior; $B A B S$ in forest $9 \%$ and beach 5\%. Smooking in family $31 \%$ and drink of alcohol $91 \%$. The Conclusion of this research showed that Mortality Index Diabettes Mellitus every 1000 people was 40\%, Morbidity index of Malaria every-1000 people were 77,78\%, Morbidity index of Heart disease was $31,03 \%$. Fertility Index pregnance $8 \%$ and Toddler $17 \%$.
\end{abstract}

Keywords: Determinant of Public Health 
Kesehatan merupakan salah satu hak asasi manusia, seperti tercantum dalam UUD 1945 yang menyatakan bahwa setiap orang berhak hidup sejahtera lahir dan bathin, mendapatkan lingkungan hidup yang baik dan sehat serta memperoleh pelayanan kesehatan. Kesehatan sebagai hak asasi manusia, mengandung suatu kewajiban untuk menyehatkan yang sakit dan berupaya mempertahankan yang sehat untuk tetap sehat (Ainy, 2010).

Masalah kesehatan masyarakat ini sangat multi kausal, sehingga pemecahannya adalah multidisiplin.Semua kegiatan baik yang langsung maupun tidak langsung untuk mencegah penyakit (preventif), promosi kesehatan (promotif), pengobatan bagi penderita (kuratif), maupun pemulihan kesehatan (rehabilitatif) adalah upaya untuk meningkatkan kesehatan masyarakat.Untuk meningkatkan upaya kesehatan masyarakat sangat diperlukan kerjasama antara masyarakat dan petugas kesehatan untuk mencegah terjadinya suatu penyakit dan adanya pemulihan kesehatan (Anwar dkk, 2016).

Secara sosiologi karakteristik masyarakat kepulauan sangatlah berbeda dengan masyarakat agraris karena perbedaan karakteristik sumber daya yang dihadapi. Wilayah kepulauan merupakan wilayah yang secara administratif jauh dari pusat kota memungkinkan terjadinya masalah kesehatan disebabkan oleh akses dan sarana prasarana tidak memadai karena kondisi geografis yang terdiri gugusan pulau yang dipisahkan oleh laut (Anwar dkk, 2016)..

Masalah kesehatan utama di daerah itu adalah kurangnya perilaku hidup bersih sehat masyarakat. Selain itu, mayoritas masyarakat membangun rumah di atas laut sehingga tidak memiliki septic tank dan limbah langsung dibuang ke laut. Gangguan kesehatan yang banyak dialami oleh masyarakat kepualauan antara laun nyeri sendi, gangguan pendengaran rungan hingga tuli kasus baritrauma, dan penyakit dekompresi yang biasa menyerang penyelam.

Risiko kesehatan selalu mengikuti setiap gerak nelayan dalam upaya memenuhi kebutuhan hidupnya.Saat melakukan penyelaman seringkali terjadi kecelakaan.Tak jarang, para nelayan tidak segera mendapat pertolongan bisa mengalami kelumpuhan, bahkan kematian. Masalah kesehatan lain adalah bahwa penyakit yang kerap diderita nelayan antara lain kurang gizi, kelainan kulit akibat paparan sinar matahari (hyperpigmentasi) baik di muka maupun di tangan, gangguan pendengaran akibat kebisingan yang ditimbulkan mesin tempel perahu, serta kelainan mata (Kartikasari, 2017).

Indikator derajat kesehatan yang merupakan hasil akhir, yang terdiri atas indikator- indikator mortalitas, indikator- indikator morbiditas, dan indikator- indikator status gizi. Indikator hasil antara, yang terdiri atas indikator- indikator keadaan lingkungan, indikator- indikator perilaku hidup masyarakat, serta indikator- indikator akses dan mutu pelayanan kesehatan. Indikator proses dan masukan, yang terdiri atas indikator- indikator pelayanan kesehatan, indikator- indikator sumber daya kesehatan, indikator- indikator menejemen kesehatan, dan indikator- indikator kontribusi sektor- sektor terkait. Indikator kesehatan yang cukup menarik untuk diamati antara lain adalah angka kematian bayi, angka kesakitan dan pemenuhan gizi. Derajat kesehatan penduduk dipengaruhi oleh faktor-faktor seperti budaya, gaya hidup, tingkat pendidikan, tingkat kesejahteraan, dan lain-lain. Faktor budaya berkaitan dengan kebiasaan penduduk pada umumnya misal; kebiasaan mencampurkan tempat tinggal dengan tempat binatang ternak, sampah yang dibuang sembarangan, penggunaan air sungai sebagai sumber air bersih.Rendahnya tingkat pendidikan masyarakat menyulitkan dalam mensosialisasikan kebiasaankebiasaan hidup yang sehat.Tingkat ekonomi yang rendah menghambat masyarakat atas akses terhadap fasilitas-fasilitas kesehatan, dan juga rendahnya tingkat pemenuhan gizi yang diperlukan tubuh (Besajja, 2013).

Beberapa indikator derajat kesehatan penduduk yang mencerminkan derajat kesehatan masyarakat, antara lain adalah angka kematian bayi (AKB/IMR), angka kematian kasar (AKK/CDR), status gizi, dan angka harapan hidup. Besarnya angka dari indikator 
tersebut berkaitan erat dengan tingkat pendidikan keluarga terutama ibu, perilaku hidup sehat, kebersihan, dan kesehatan lingkungan serta sarana pelayanan kesehatan yang tersedia. Selain faktor-faktor diatas, tinggi rendahnya $\mathrm{AKB}$ juga dipengaruhi oleh masa persalinan, pemberian air susu ibu (ASI) dan makanan, serta pemberian imunisasi. Oleh karena itu, lamanya pemberian ASI dan kelengkapan pemberian imunisasi perlu diperhatikan (Aprilianti, 2009).

Penelitian ini menjadi sangat penting karena saat ini Pulau Lipang adalah Wilayah kepulauan yang merupakan wilayah yang secara administratif jauh dari pusat kota memungkinkan terjadinya masalah kesehatan disebabkan oleh akses dan sarana prasarana tidak memadai karena kondisi geografis yang terdiri dari gugusan pulau yang dipisahkan oleh laut. Derajat kesehatan masyarakat sangat penting diketahui dalam rangka penyusunan dan implementasi program kesehatan yang tepat dan berkelanjutan.

\section{METODE PENELITIAN}

Penelitian ini menggunakan rancangan deskritif dengan metode survey untuk mengetahui derajat kesehatan masyarakat di Pulau Lipang Kecamatan Kendahe Kabupaten Kepulauan Sangihe. Penelitian ini berlangsung selama kurang lebih 3 bulan yakni pada bulan Juni 2019 s/d Agustus 2019. Populasi dalam penelitian ini yaitu seluruh Kepala Keluarga Pulau Lipang berjumlah 106 Kepala Keluarga dengan kriteria inklusi tinggal di Pulau Lipang selama penelitian dan bersedia menjadi responden. Sampel dalam penelitian ini menggunakan total sampling. Dan berdasarkan kriteria inklusi maka responden berjumlah 77 Kepala Keluarga.

\section{HASIL DAN PEMBAHASAN}

Kampung Lipang memiliki 106 Kepala Keluarga dan memenuhi kriteria inklusi berjumlah 77 KK dengan hasil penelitian sebagai berikut :

\section{A. Karakteristik Umum Responden}

Tabel 1. Distribusi Karakteristik Responden ( $n=77)$

\begin{tabular}{|c|c|c|}
\hline Karakteristik & Jumlah & Persentase \\
\hline \multicolumn{3}{|l|}{ Umur } \\
\hline$<30$ tahun & 16 & 21 \\
\hline $31-45$ tahun & 40 & 52 \\
\hline$>46$ tahun & 21 & 27 \\
\hline \multicolumn{3}{|l|}{ Tingkat pendidikan } \\
\hline Tidak tamat SD & 15 & 19 \\
\hline SD & 33 & 43 \\
\hline SMP & 16 & 21 \\
\hline SMA & 11 & 14 \\
\hline PT & 2 & 3 \\
\hline \multicolumn{3}{|l|}{ Pekerjaan } \\
\hline Nelayan & 31 & 40.2 \\
\hline Pegawai Negeri Sipil & 8 & 10.4 \\
\hline Petani & 7 & 9.1 \\
\hline Buruh & 3 & 3.9 \\
\hline Ibu Rumah Tangga & 27 & 35.1 \\
\hline Kader & 1 & 1.3 \\
\hline
\end{tabular}

Tabel 1 menunjukkan bahwa umur responden terbanyak adalah umur 31 - 45 tahun yaitu 40 responden $(52 \%)$. Pendidikan responden terbanyak adalah Sekolah Dasar (SD) sebanyak 33 responden (43\%). Pekerjaan responden terbanyak adalah nelayan sebanyak 31 responden $(40.2 \%)$.

\section{B. Situasi Derajat Kesehatan}

1. Jumlah kematian (Indeks Mortalitas) yang dicatat selama 1 tahun per-1000 penduduk

Tabel 2. Jumlah kematian (Indeks Mortalitas) yang dicatat selama 1 tahun per-1000 penduduk

\begin{tabular}{ccc}
\hline Penyakit penyebab & Jumlah & Persentase \\
\hline Stroke & 1 & 20 \\
Asma Bronchial & 1 & 20 \\
Diabetes Melitus & 2 & 40 \\
Kecelakaan & 1 & 20 \\
\hline Total & 5 & 100 \\
\hline AKK & $5 / 77 \times 1000$ & $64.94 / 1000$ \\
& & penduduk \\
\hline
\end{tabular}

Tabel 2 menunjukkan bahwa jumlah kematian 1 tahun terakhir terbanyak karena Diabetes Melitus berjumlah 2 responden (40\%). 
11 Jurnal Ilmiah Sesebanua, Volume 4, Nomor 1, Maret 2020, hlm. 8-20

2. Jumlah Penderita (Indeks Morbiditas) Penyakit Menular per-1000 penduduk

Tabel 3. Jumlah Penderita (Indeks Morbiditas)

Penyakit Menular per-1000 penduduk

\begin{tabular}{ccc}
\hline Penyakit menular & Jumlah & Persentase \\
\hline Malaria & 14 & 77.78 \\
Kaki Gajah & 1 & 5.55 \\
Penyakit Kulit & 3 & 16.67 \\
\hline Total & 18 & 100 \\
\hline Angka Morbiditas & $18 / 77 \times 1000$ & $233.76 / 1000$ \\
& & penduduk \\
\hline
\end{tabular}

Tabel 3 menunjukkan bahwa penderita penyakit menular terbanyak adalah malaria sebanyak 14 responden $(77.78 \%)$.

3. Jumlah Penderita (Indeks Morbiditas) Penyakit

Tidak Menular per-1000 penduduk

Tabel 4. Jumlah Penderita (Indeks Morbiditas)

Penyakit Tidak Menular per-1000 penduduk

\begin{tabular}{ccc}
\hline $\begin{array}{c}\text { Penyakit tidak } \\
\text { menular }\end{array}$ & Jumlah & Persentase \\
\hline Penyakit Jantung & 9 & 31.03 \\
Hipertensi & 8 & 27.58 \\
Stroke & 2 & 6.90 \\
Diabetes Mellitus & 3 & 10.34 \\
Penyakit Ginjal & 6 & 20.68 \\
Kanker & 1 & 3.45 \\
\hline Total & 29 & 100 \\
\hline Angka Morbiditas & $29 / 77 \times 1000$ & $376.62 / 1000$ \\
PTM & & penduduk \\
\hline
\end{tabular}

Tabel 4 menunjukkan morbiditas penyakit tidak menular 1 tahun terakhir terbanyak adalah penyakit jantung (31.03\%).

4. Indeks Fertilitas ibu hamil di Pulau Lipang

Tabel 5. Indeks Fertilitas ibu hamil di Pulau Lipang

$$
(\mathrm{n}=91)
$$

\begin{tabular}{ccc}
\hline Ibu hamil & $\begin{array}{c}\text { Jumlah Wanita usia } \\
\text { Subur (WUS) }\end{array}$ & Persentase \\
\hline Ya & 7 & 8 \\
Tidak & 84 & 92 \\
\hline
\end{tabular}

Tabel 5 menunjukkan jumlah ibu hamil di Pulau Lipang adalah 7 orang (8\%).

5. Indeks Fertilitas Balita di Pulau Lipang

Tabel 6. Indeks Fertilitas Balita di Pulau Lipang $(n=77)$

\begin{tabular}{ccc}
\hline Balita & Jumlah KK & Persentase \\
\hline Ya & 18 & 16.88 \\
Tidak & 64 & 83.12 \\
\hline
\end{tabular}

Tabel 6 menunjukkan jumlah balita di Pulau Lipang adalah 13 KK (16.88\%).

6. Distribusi tempat persalinan bagi ibu hamil

Tabel 7. Distribusi tempat persalinan bagi ibu hamil

\begin{tabular}{lll}
\multicolumn{2}{c}{$(\mathrm{n}=7)$} & \\
\hline Tempat persalinan & Jumlah & Persentase \\
\hline Pelayanan kesehatan & 5 & 71.43 \\
Biang kampong/ Dukun beranak & 2 & 28.57 \\
\hline
\end{tabular}

Tabel 7 menunjukkan bahwa tempat persalinan terbanyak di pelayanan kesehatan yaitu 5 org ibu hamil $(71.43 \%)$.

7. Distribusi keluarga yang menggunakan kontrasepsi

Tabel 8. Distribusi keluarga yang menggunakan kontrasepsi $(\mathrm{n}=77)$

\begin{tabular}{ccc}
\hline Menggunakan kontrasepsi & Jumlah & Persentase \\
\hline Ya & 43 & 55.84 \\
Tidak & 34 & 44.16 \\
\hline
\end{tabular}

Tabel 8 menunjukkan bahwa keluarga yang menggunakan kontrasepsi adalah 43 keluarga $(55.84 \%)$.

8. Distribusi jenis kontrasepsi yang digunakan

Tabel 9. Distribusi jenis kontrasepsi $(n=43)$

\begin{tabular}{ccc}
\hline Jenis Kontrasepsi & Jumlah & Persentase \\
\hline Pil & 8 & 18.60 \\
Suntik 3 bulan & 33 & 76.74 \\
Implant & 2 & 4.65 \\
IUD & 0 & 0 \\
\hline
\end{tabular}

Tabel 9 menunjukkan bahwa jenis kontrasepsi terbanyak yang digunakan adalah Suntik 3 bulan sejumlah 33 keluarga (76.74\%). 


\section{Indikator status Gizi}

Tabel 10. Distribusi indikator status gizi

\begin{tabular}{|c|c|c|}
\hline Diberikan ASI & Jumlah & Persentase \\
\hline Ya & 9 & 69.23 \\
\hline Tidak & 4 & 30.77 \\
\hline \multicolumn{3}{|c|}{ Ke Posyandu dan mendapat imunisasi } \\
\hline Ya & 11 & 84.62 \\
\hline Tidak & 2 & 15.38 \\
\hline \multicolumn{3}{|l|}{ Imunisasi } \\
\hline BCG & 0 & 0 \\
\hline Hepatitis B 0 & 0 & 0 \\
\hline DPT & 2 & 15.38 \\
\hline Hepatitis & 1 & 7.69 \\
\hline Polio & 5 & 38.46 \\
\hline Campak & 5 & 38.46 \\
\hline Rubella & 3 & 23.08 \\
\hline
\end{tabular}

Tabel 10 menunjukkan bahwa bayi/balita yang diberikan tidak diberikan ASI berjumlah 4 org (30.77\%). Bayi/balita yang ditimbang di Posyandu dan mendapat imunisasi berjumlah 11 org ( $84.62 \%)$. Bayi/Balita yang sudah diberikan ke bayi/balita terbanyak adalah Polio dan Campak (38.46\%).

\section{Indikator keadaan lingkungan}

Tabel 11. Distribusi indikator keadaan lingkungan

\begin{tabular}{cccc}
\hline & variabel & Jumlah & Persentase \\
\hline Sumber air & Air hujan & 72 & 93.51 \\
Sumur & 9 & 11.69 \\
PDAM & 0 & 0 \\
\hline Sumber air untuk minum \&masak & & \\
Air hujan & 77 & 100 \\
Sumur & 0 & 0 \\
PDAM & 0 & 0 \\
\hline
\end{tabular}

Tabel 11 menunjukkan bahwa sumber air yang digunakan untuk kebutuhan rumah tangga adalah air hujan yaitu 72 keluarga $(93.51 \%)$. Sumber air untuk minum dan masak menggunakan air hujan sejumlah 77 keluarga (100\%).

\section{E. Upaya Pelayanan Kesehatan}

Tabel 12. Distribusi upaya pelayanan kesehatan

\begin{tabular}{|c|c|c|}
\hline Variabel & Jumlah & Persentase \\
\hline \multicolumn{3}{|l|}{ Upaya pelayanan kesehatan } \\
\hline $\mathrm{Ya}$ & 72 & 93.51 \\
\hline Tidak & 5 & 6.49 \\
\hline \multicolumn{3}{|l|}{ Jenis pelayanan kesehatan } \\
\hline Penimbangan bayi & 2 & 2.60 \\
\hline Imunisasi & 2 & 2.60 \\
\hline Pengobatan & 72 & 93.50 \\
\hline Pemeriksaan kehamilan & 1 & 1.30 \\
\hline Persalinan & - & \\
\hline \multicolumn{3}{|l|}{ Jenis jaminan kesehatan } \\
\hline Bayar sendiri & 13 & 16.88 \\
\hline Pakai kartu BPJS & 56 & 72.72 \\
\hline Pakai Kartu KIS & 8 & 10.40 \\
\hline \multicolumn{3}{|l|}{ Penyuluhan oleh petugas kes } \\
\hline Ya & 57 & 74.03 \\
\hline Tidak & 20 & 25.97 \\
\hline \multicolumn{3}{|l|}{ Jenis Pengobatan tradisional } \\
\hline Dukun kampung & 2 & 4.88 \\
\hline Jamu & 0 & 0 \\
\hline Pijat & 39 & 95.12 \\
\hline Dukun beranak & 0 & 0 \\
\hline
\end{tabular}

Tabel 12 menunjukkan bahwa upaya masyarakat untuk berobat ke pelayanan kesehatan berjumlah 72 keluarga $(93.51 \%)$. Jenis pelayanan kesehatan yang dimanfaatkan oleh keluarga terbanyak adalah pengobatan 72 keluarga (93.50\%). Jenis jaminan kesehatan yang digunakan terbanyak adalah memakai kartu BPJS sejumlah 56 keluarga (72.72\%). Petugas yang melakukan penyuluhan kesehatan kepada 57 keluarga (74.03\%). Masyarakat yang pernah melakukan pengobatan tradisional berjumlah 41 keluarga $(53.25 \%)$. Jenis pengobatan tradisional yang sering dilakukan adalah pijat sejumlah 39 keluarga $(95.12 \%)$. 


\section{F. Perilaku Kesehatan}

Tabel 13. Distribusi perilaku kesehatan

\begin{tabular}{|c|c|c|}
\hline Variabel & Jumlah & Persentase \\
\hline \multicolumn{3}{|l|}{ Air minum dimasak } \\
\hline $\mathrm{Ya}$ & 77 & 100 \\
\hline Tidak & 0 & 0 \\
\hline \multicolumn{3}{|l|}{ Menguras bak mandi } \\
\hline Seminggu sekali & 29 & 37.66 \\
\hline Dua minggu sekali & 15 & 19.48 \\
\hline Tiga minggu sekali & 13 & 16.88 \\
\hline Sebulan sekali & 17 & 22.08 \\
\hline Dua bulan sekali & 3 & 3.90 \\
\hline \multicolumn{3}{|l|}{ Waktu mencuci tangan } \\
\hline Sebelum makan & 60 & 77.92 \\
\hline Setelah buang air & 2 & 2.60 \\
\hline Sebelum menyiapkan makan & 6 & 7.79 \\
\hline Setelah memegang binatang & 0 & 0 \\
\hline $\begin{array}{c}\text { Sebelum makan/buang air/menyiapkan } \\
\text { makan/pegang binatang }\end{array}$ & 2 & 2.60 \\
\hline \multicolumn{3}{|l|}{ Buang Air Besar } \\
\hline Jamban & 66 & 85.71 \\
\hline Hutan & 7 & 9.10 \\
\hline Pantai & 4 & 5.19 \\
\hline \multicolumn{3}{|l|}{ Waktu gosok gigi } \\
\hline Saat Mandi pagi & 2 & 2.60 \\
\hline Saat mandi pagi dan sore & 36 & 46.75 \\
\hline Mandi pagi, mandi sore, makan pagi & 30 & 38.96 \\
\hline Sesudah bangun pagi & 9 & 11.69 \\
\hline \multicolumn{3}{|l|}{ Merokok } \\
\hline Ya & 24 & 31.17 \\
\hline Tidak & 53 & 68.83 \\
\hline \multicolumn{3}{|l|}{ Minum Alkohol } \\
\hline $\mathrm{Ya}$ & 70 & 90.91 \\
\hline Tidak & 7 & 9.09 \\
\hline
\end{tabular}

Tabel 13 menunjukkan bahwa distribusi keluarga berdasarkan air minum yang dimasak berjumlah 77 keluarga (100\%). Keluarga yang menguras bak mandi terbanyak adalah seminggu sekali berjumlah 29 org (37.66\%). Waktu mencuci tangan terbanyak adalah sebelum makan sebanyak 60 responden (77.92\%). Kebiasaan Buang Air Besar terbanyak di jamban sejumlah 66 responden $(85.71 \%)$. Waktu menggosok gigi terbanyak saat mandi pagi dan mandi sore sejumlah 36 responden $(46.75 \%)$. Merokok dalam keluarga ada 24 keluarga (31.17\%). Keluarga yang mengonsumsi alcohol berjumlah 70 keluarga $(90.91 \%)$.

\section{Pembahasan}

Derajat kesehatan merupakan salah satu ukuran kesejahteraan dan kualitas sumber daya manusia. Sebagaimana lazimnya untuk menggambarkan derajat kesehatan digunakan indicator kualitas utama seperti angka kematian, kesakitan, kelahiran, status gizi dan factor lainnya yang mempengaruhi derajat kesehatan seperti indicator kesehatan lingkungan, upaya pelayanan kesehatan dan perilaku kesehatan.

\section{Mortalitas}

Mortalitas adalah indeks kesehatan yang penting untuk menentukan derajat kesehatan masyarakat.Tinggi rendahnya tingkat mortalitas penduduk disuatu daerah tidak hanya mempengaruhi pertumbuhan penduduk, tetapi juga merupakan barometer dari tinggi rendahnya tingkat kesehatan masyarakat di daerah tersebut (Septia, 2016). Penyebab kematian 1 tahun terakhir terbanyak karena Diabetes Melitus berjumlah 2 responden $(40 \%)$. Karakteristik responden di Pulau Lipang menunjukkan bahwa umur responden terbanyak adalah umur 31 - 45 tahun yaitu 40 responden (52\%). Umur ini tergolong dalam usia pertengahan (paruh baya). Umur seseorang mempengaruhi derajat kesehatan masyarakat.Semakin tinggi umur seseorang semakin rentan seseorang terpapar dengan penyakit terutama penyakit degenerative. Berdasarkan perhitungan Angka Kematian Kasar (AKK) menunjukkan bahwa jumlah kematian sebesar 64, 94 per 1000 penduduk.Hal ini sejalan dengan berbagai penelitian epidemiologi yang menunjukkan adanya kecenderungan peningkatan angka insiden dan prevalensi DM Tipe-2 di berbagai penjuru dunia. Berdasarkan perolehan data Internasional Diabtes Federation (IDF) 2013 menunjukkan bahwa tingkat prevalensi global penderita DM pada tahun 2013 sebesar 382 kasus dan diperkirakan pada tahun 2035 mengalami peningkatan menjadi 55\% (592 kasus) diantara usia penderita DM 40-59 tahun.

\section{Morbiditas}

Penyakit menular terbanyak adalah malaria sebanyak 14 responden $(77.78 \%)$. Angka morbiditas 
penyakit menular malaria pada penduduk Kampung Lipang adalah 233.766 per 1.000 penduduk.Penyakit menular adalah penyakit yang disebabkan oleh bibit tertentu atau oleh produk toksin yang didapatkan melalui penularan bibit penyakit atau toksin yang diproduksi oleh bibit penyakit tersebut dari orang terinfeksi; dari reservoir kepada orang yang rentan, baik secara langsung maupun tidak langsung, tumbuh tumbuhan atau binatang penjamu; vector atau melalui lingkungan. Malaria merupakan penyakit ancaman terbesar yang mengakibatkan penderitanya mengalami kematian. Mordibilitas penyakit tidak menular (PTM) 1 tahun terakhir terbanyak adalah penyakit jantung (31.03\%).Angka morbiditas PTM adalah 376.62 per 1000 penduduk. Penyakit Tidak Menular merupakan ancaman di era milenial ini.Penyakit tidak menular saat ini tidak kalah prevalensinya didunia dengan penyakit mneular, bahkan menjadi penyebab kematian terbanyak saat ini di Indonesia. Penyakit tidak menular antara lain jantung, stroke, diabetes mellitus (DM), hipertensi, asam urat dan sebagainya. Penyakit yang tidak disebabkan oleh virus atau bakteri dan tidak ditularkan kepada orang lain. WHO menyebutkan puluhan juta orang didunia meninggal. Penyebab penyakit tidak menular antara lain makanan tidak sehat, kebiasaan merokok, penggunaan alcohol dan gaya hidup tidak sehat. Dalam menangani masalah penyakit tidak menular, tidak cukup dengan obat kimia saja, tetapi harus ditunjang dengan peran aktif petugas kesehatan untuk memberikan penyuluhan-penyuluhan, kampanye-kampanye secara terus menerus. Upaya upaya ini akan memudahkan langkah Indonesia mencapai target mengurangi angka kesakitan dan angka kematian akibat penyakit tidak menular pada tahun 2025.

\section{Fertilitas}

Jumlah ibu hamil di Pulau Lipang adalah 7 orang $(9.09 \%)$ dan jumlah balita di Pulau Lipang adalah 13 KK (16.88\%). Kehamilan merupakan hal yang sangat diinginkan oleh suami istri untuk melanjutkan keturunannya.Pemeliharaan kesehatan ibu hamil sangat penting untuk kelangsungan pertumbuhan dan perkembangan janin.Untuk itu setiap ibu hamil harus memperhatikan kesehatannya (Mubarak, 2014). Demikian pula dengan kesehatan balita. Balita merupakan penerus bangsa, maka kualitas tumbuh kembangnya perlu mendapat perhatian serius yaitu memberi gizi yang baik, stimulasi yang memadai serta pelayanan kesehatan berkualitas sehingga dapat meningkatkan kualitas hidup anak agar mencapai tumbuh kembang optimal baik fisik, mental, emosional maupun social serta memiliki inteligensi majemuk sesuai dengan potensi genetiknya.

Tempat persalinan terbanyak di pelayanan kesehatan yaitu 5 org ibu hamil (71.43\%). Pelayanan kesehatan merupakan suatu upaya yang diselenggarakan sendiri atau secara bersama-sama dalam suatu organisasi untuk memelihara dan meningkatkan kesehatan, mencegah dan menyembuhkan penyakit serta memulihkan kesehatan, perorangan, keluarga, kelompok ataupun masyarakat. Pelayanan kesehatan yang diselenggarakan di puskesmas, klinik, dan rumah sakit diatur secara umum dalam UU Kesehatan, dalam Pasal 54 ayat (1) UU Kesehatan berbunyi bahwa penyelenggaraan pelayanan kesehatan dilaksanakan secara bertanggung jawab, aman, bermutu, serta merata dan nondiskriminatif. Dalam hal ini setiap orang atau pasien dapat memperoleh kegiatan pelayanan kesehatan secara professional, aman, bermutu, anti diskriminasi dan efektif serta lebih mendahulukan pertolongan keselamatan nyawa pasien dibanding kepentingan lainnya.Masyarakat Pulau Lipang telah melaksanakan amanat Undang Undang Kesehatan sehingga kegiatan pelayanan kesehatan yang aman, bermutu dan professional dapat diterima oleh anggota masyarakat.

Keluarga yang menggunakan kontrasepsi adalah 43 keluarga (55.84\%) dan jenis kontrasepsi terbanyak yang digunakan adalah Suntik 3 bulan sejumlah 33 keluarga (76.74\%). Program KB memiliki potensi untuk menunjang Pembangunan Kesehatan, yakni pengendalian laju pertumbuhan penduduk, menurunkan Angka Kematian Ibu (AKI). Keberhasilan program ini ditentukan dari berbagai factor yang ada diantaranya 
tingkat pendidikan, tingkat kemampuan ekonomi dan sosial serta tingkat pemahaman agama.Dengan berhasilnya pelaksanaan KB diharapkan angka kelahiran dapat diturunkan, sehingga kecepatan perkembangan penduduk tidak melebihi kemampuan kenaikan produksi. Dengan demikian taraf kehidupan dan kesejahteraan masyarakat diharapkan akan lebih meningkat. Tingkat pencapaian pelayanan keluarga berencana dapat dilihat dari cakupan peserta KB yang sedang menggunakan alat/ metode kontrasepsi (KB Aktif). Diharapkan keberhasilan yang dicapai dalam pengendalian laju pertumbuhan penduduk dan peningkatan kualitas sumber daya manusia akan berpengaruh terhadap keberhasilan program-program lainnya.

\section{Status Gizi}

Bayi/balita diberikan ASI berjumlah 9 orang (69.23\%). Air susu ibu merupakan makanan bayi yang paling lengkap kandungan gizi, steril tetapi amat sangat mahal karena sampai saat ini, belum ada makanan susu formula yang dapat menyamai kandungan Gizi dari susu ibu. Data yang diperoleh ternyata ibu yang memberi asi secara eklusif sangat rendah. Gizi untuk bayi yang paling sempurna dan paling murah bagi bayi adalah Air Susu Ibu (ASI).Bayi atau anak balita yang kekurangan gizi sangat rentan terhadap penyakitpenyakit infeksi termasuk diare dan infkesi saluran akut, utamanya pneumonia. Kekurangan gizi pada bayi akan berakibat terhadap munculnya masalah kesehatan lain dan akhirnya akan berdampak terhadap menurunnya derajat kesehatan masyaraat.

Bayi/balita yang ditimbang di Posyandu dan mendapat imunisasi berjumlah 11 orang $(84.62 \%)$ dan tabel 12 menunjukkan bahwa distribusi imunisasi yang sudah diberikan ke bayi/balita terbanyak adalah Polio dan Campak (38.46\%). Sedangkan imunisasi BCG, Hepatitis B0 tidak pernah diberikan, dan imunisasi Hepatitis hanya diberikan kepada seorang balita.Salah satu upaya pencegahan penyakit, yaitu pemberian imunisasi. Tujuan jangka pendek dari pelayanan imunisasi adalah pencegahan penyakit secara perorangan atau kelompok, sedangkan tujuan jangka panjang adalah eradikasi atau eliminasi suatu penyakit.Imunisasi biasanya lebih fokus diberikan kepada anak-anak karena sistem kekebalan tubuh mereka masih belum sebaik orang dewasa, sehingga rentan terhadap serangan penyakit berbahaya. Kondisi laut yang sering bergelombang tinggi di perairan Pulau Lipang menyebabkan terhambatnya pelayanan kesehatan terutama kunjungan kerja dari Puskesmas Kendahe dalam rangka Posyandu balita sehingga dalam setahun ini (tahun 2019) baru satu kali kunjungan kesehatan dari tim kesehatan kecamatan ke Pulau Lipang. Hal ini berdampak pada jadwal imunisasi yang tidak teratur dan penyediaan vaksin yang tidak cukup dan tidak sesuai dengan kebutuhan, serta informasi tentang pelayanan imunisasi yang kurang memadai kepada masyarakat yang akan menurunkan cakupan imunisasi. Cakupan imunisasi yang kurang akan mendorong tingginya angka kesakitan akibat penyakit yang hanya bisa dicegah dengan imunisasi. Masalah ini berdampak pada program pengembangan imuniasi dalam rangka pencegahan penularan terhadap penyakit yang dapat dicegah dengan imunisasi (PD3I) yaitu tuberculosis, difteri, pertussis, campak, polio tetanus serta hepatitis B. Target jangkauan imunisasi bayi ditujukan dengan cakupan imunisasi BCG, HBO, DPT,Hb,HiB 1 karena imunisasi ini merupakan salah satu antigen kontak pertama dari semua imuniassi yang diberikan pada bayi. Imunisasi tidak cukup hanya dilakukan satu kali, tetapi harus dilakukan secara bertahap dan lengkap terhadap berbagai penyakit yang sangat membahayakan kesehatan dan hidup anak.

\section{Indikator Lingkungan}

Sumber air yang digunakan untuk kebutuhan rumah tangga adalah menggunakan air hujan yaitu 72 keluarga $(93.51 \%)$. Sumber air untuk minum dan masak menggunakan air hujan sejumlah 77 keluarga (100\%). Hal ini sejalan dengan penelitian Anuar (2015) tentang Analisis Kualitas air hujan sebagai sumber air minum terhadap kesehatan masyarakat (Studi Kasus di Kecamatan Bagansiapiapi) bahwa kualitas air hujan di lokasi penelitian berdasarkan hasil laboratorium jika 
ditinjau dari parameter kimia anorganik, parameter fisik, parameter kimiawi masih di bawah baku mutu kualitas air minum yang dipersyaratkan menurut Permenkes No. 492/Menkes/Per/IV/2010. Berdasarkan hasil laboratorium terhadap kandungan air hujan di lokasi penelitian bahwa air hujan tersebut masih bisa dikonsumsi oleh masyarakat dan tidak berdampak bagi kesehatan.Timbulnya berbagai penyakit menurut hasil penelitian ini bukan disebabkan oleh air hujan, namun disebabkan oleh perilaku masyarakat dalam menciptakan sanitasi lingkungan hidup yang sehat di sekitar pemukiman yang masih rendah.

\section{Upaya Pelayanan Kesehatan}

Upaya masyarakat untuk berobat ke pelayanan kesehatan berjumlah 72 keluarga (93.51\%).Undangundang Dasar 1945 menekankan bahwa negara wajib melayani setiap warga negara untuk memenuhi kebutuhan dasarnya dalam rangka meningkatkan kesejahteraan masyarakat.Salah satunya adalah mengenai pelayanan kesehatan.Seperti yang kita ketahui bahwa pelayanan kesehatan merupakan pelayanan yang penting bagi masyarakat.Pemerintah wajib memberikan pelayanan tersebut untuk menjadikan masyarakat Indonesia menjadi sehat. Disisi lain pemerintah juga harus bisa memberikan pelayanan yang baik dan berkualitas kepada masyarakat secara adil. Gambaran situasi dan kondisi pelayanan di bidang kesehatan oleh pemerintah saat ini cukup memprihatinkan sehingga masyarakat banyak yang tidak puas.Pelayanan yang diberikan terlalu berbelitbelit, banyaknya biaya dan waktu yang sangat lama, sehingga pelayanan yang diberikan cenderung tidak berkualitas.Hal di atas menyebabkan tingkat kesehatan masyarakat menurun.

Jenis pelayanan kesehatan yang dimanfaatkan oleh keluarga terbanyak adalah pengobatan sejumlah 72 keluarga (93.50\%) dan tabel 19 menunjukkan bahwa jenis jaminan kesehatan yang digunakan terbanyak adalah memakai kartu BPJS sejumlah 56 keluarga $(72.72 \%)$. Sesuai dengan Undang-Undang Nomor 40 Tahun 2004 tentang Sistem Jaminan Sosial Nasional, setiap orang berhak atas jaminan sosial untuk dapat memenuhi kebutuhan dasar hidup yang layak. Untuk memberikan jaminan sosial yang menyeluruh, maka negara mengembangkan Sistem Jaminan Sosial Nasional bagi seluruh rakyat Indonesia.BPJS Kesehatan merupakan asuransi sosial yang dalam penyelenggaraannya melibatkan partisipasi seluruh pihak, mulai dari masyarakat, pemerintah, fasilitas kesehatan, tenaga medis, badan usaha, serta stakeholders lainnya. BPJS Kesehatan menganut prinsip gotong royong, yang mana prinsip tersebut kemudian diterapkan dalam sistem pembiayan iuran peserta JKN-KIS, dimana peserta yang sehat membantu peserta yang sakit.BPJS Kesehatan menanggung biaya pelayanan kesehatan seluruh peserta JKN-KIS yang membutuhkan, mulai dari peserta dengan penyakit ringan hingga peserta yang memerlukan penanganan medis seumur hidup seperti cuci darah dan hemofilia, atau yang berbiaya besar seperti operasi jantung dan kemoterapi. Agar program JKN-KIS yang dikelola BPJS Kesehatan dapat berkelanjutan dan memberi manfaat bagi peserta yang membutuhkan, maka jumlah peserta sehat yang terdaftar harus lebih banyak dibandingkan jumlah peserta yang sakit.

Petugas yang melakukan penyuluhan kesehatan kepada 57 keluarga (74.03\%). Penyuluhan kesehatan merupakan suatu proses yang ditujukan kepada individu atau kelompok penduduk agar mereka berperilaku sehat dalam menjaga dan memelihara kesehatan mereka. Penyuluhan kesehatan dimulai dari masyarakat dalam keadaan seperti apa adanya yaitu pandangan mereka selamai ini terhadap masalah kesehatan. Dengan memberikan penyuluhan kesehatan kepada mereka dimaksudkan untuk mengembangkan sikap dan tanggung jawab sebagai individu, anggota keluarga, anggota masyarakat dalam masalah kesehatan.

Masyarakat yang pernah melakukan pengobatan tradisional berjumlah 41 keluarga (53.25\%) dan tabel 22 menunjukkan bahwa jenis pengobatan tradisional yang sering dilakukan adalah pijat sejumlah 39 keluarga $(95.12 \%)$. Hal ini sejalan 
dengan penelitian Kartika dkk (2016) tentang pelayanan kesehatan tradisional dan perlindungan hokum bagi pasien bahwa responden mengetahui tentang jenis - jenis pengobatan tradisional, paling popular jenis pengobatan tradisional yang diketahui oleh responden adalah pengobatan tradisional (akupuntur, pijat, jamu) dan terapi energi, dan pendapat terbanyak menurut responden tentang pengertian pengobatan tradisional adalah pengobatan yang obatnya berasal dari tumbuhan, hewan, dan bahan mineral. Pijat, akupressure dan akupuntur adalah jenis pengobatan yang sering dilakukan oleh responden untuk menyembuhkan penyakit yang sedang di deritanya. Jenis penyakit yang di periksakan mulai dari jenis penyakit ringan sampai penyakit yang berat, yaitu jenis penyakitnya flu, rematik, diabetes, kanker, gagal ginjal, down syndrome, gizi buruk, obesitas, kolesterol, penyempitan syaraf, anyang-anyangan, lambat berbicara, gagal prostrate, usus mepet, dan tumbuh kembang otak lambat

Pelayanan kesehatan tradisional merupakan terapi alternatif pengganti untuk memecahkan masalah kesehatan masyarakat.Perkembangan pelayanan kesehatan tradisional, disertai dengan antusiasme orang dalam pengobatan tradisional, menegaskan bahwa pemerintah memiliki tugas untuk meningkatkan dan mengontrol pelayanan pengobatan tradisional sebagai perwujudan perlindungan untuk masyarakat. Melalui undang-undang N0.36 Tahun 2009 Tentang Kesehatan kemudian didukung dengan peraturan Kepmenkes RI No 10761Menkes/SKIVII1/2003 tentang Penyelenggaraan Pengobatan Tradisional dimana pemerintah membentuk Sentra Pengembangan Dan Penerapan Pengobatan Tradisional (SP3T) yang diwajibkan untuk melakukan pemeriksaan pada setiap pelayanan pengobatan tradisional. Menjadi tanggung jawab pemerintah untuk menaikkan derajat kesehatan masyarakat secara optimal selain menggunakan pelayanan kesehatan formal/ modern juga menggunakan pengobatan tradisional.Pengobatan tradisional yang telah terbukti manfaat dan keamanannya diharapkan secara bersama-sama dapat memberikan layanan kesehatan kepada masyarakat.Hal ini diatur dalam Pasal 59 Undang-Undang Nomor 36 Tahun 2009.Pengobatan tradisional yang telah dan dapat dipertanggungjawabkan manfaat dan keamanannya perlu terus ditingkatkan serta dikembangkan untuk mewujudkan derajat kesehatan masyarakat yang optimal.

\section{Perilaku kesehatan}

Perilaku kesehatan pada dasarnya adalah suatu respons seseorang (organisme) terhadap stimulus yang berkaitan dengan sakit penyakit, system pelayanan kesehatan, makanan serta lingkungan.Respons atau reaksi manusia, baik bersifat pasif (pengetahuan, persepsi, dan sikap) maupun bersifat aktif (tindakan yang nyata atau praktis).Sedangkan stimulus atau rangsangan disini terdiri empat unsur pokok yakni; sakit dan penyakit, system pelayanan kesehatan dan lingkungan (Notoatmodjo, 2011). Air minum yang dimasak berjumlah 77 keluarga (100\%). Perilaku keluarga ini menunjukkan perilaku pencegahan penyakit dan perilaku sehubungan dengan peningkatan dan pemeliharaan kesehatan. Air minum yang di masak merupakan cara keluarga untuk mematikan kuman, bakteri akibat pencemaran lingkungan agar tidak masuk dalam system pencernaan yang akan membahayakan system pencernaan yang dapat menimbulkan sakit penyakit.

Keluarga yang menguras bak mandi terbanyak adalah seminggu sekali berjumlah 29 org (37.66\%).Pengurasan bak mandi hendaknya dilakukan 2 kali dalam seminggu.Namun karena kondisi geografis dan kemarau panjang di Pulau Lipang menimbulkan pengurasan bak mandi tidak dilakukan karena masyarakat melakukan pengematan air. Faktor yang mempengaruhi kejadian penyakit demam berdarah dengue antara lain faktor host, lingkungan, perilaku hidup bersih dan sehat serta faktor virusnya sendiri. Penelitian ini sesuai dengan penelitian yang dilakukan oleh Paranata tahun 2010 tentang gambaran Perilaku pemanfaatan ventilasi, penutupan penampungan air pengurasan bak mandi untuk mencegah kejadian Demam berdarah Dengue di 
Wilayah Puskesmas Pajang Surakarta bahwa kasus demam berdarah dengue sebanyak 533 kasus. Berdasarkan hasil studi pendahuluan diperoleh informasi bahwa 6 dari 10 kepala keluarga telah memanfaatkan ventilasi, membersihkan saluran air got di depan rumah, menguras bak penampungan air dan menutup serta, menguras bak mandi 2 kali dalam seminggu memberikan serbuk abate pada bak mandi. Namun sebanyak 4 keluarga masih tidak selalu membersihkan bak mandi 2 kali seminggu, Hasil penelitian menunjukkan 53,3\% responden masih buruk dalam pemanfaatan ventilasi, $76,7 \%$ responden tidak melakukan penutupan penampungan air, 56,7\% responden masih memiliki kebiasaan buruk dalam pengurasan bak mandi kurang dari 2 kali seminggu.

Waktu mencuci tangan terbanyak adalah sebelum makan sebanyak 60 responden (77.92\%). Dalam pemberantasan penyakit menular, upaya untuk melindungi diri terhadap penyakit menjadi tanggung jawab individu dalam menjaga kesehatan mereka dan mengurangi penyebaran penyakit, terutama penyakit yang ditularkan melalui kontak langsung. Upaya-upaya yang dilakukan antara lain selalu mencuci tangan setelah kencing, buang air besar, dan sebelum makan dan minum. Cuci tangan setelah menyentuh penderita dan memegang barang-barang milik penderita.

Kebiasaan Buang Air Besar terbanyak di jamban sejumlah 66 responden $(85.71 \%)$.Namun ada juga masyarakat Pulau Lipang tidak melakukan kebiasaan Buang Air Besar di Jamban. Hal ini sama dengan penelitian yang dilakukan oleh Kurniawati dkk tentang faktor-faktor yang berpengaruh terhadap perilaku kepala keluarga dalam pemanfaatan jamban di pemukiman kampung nelayan Tambak Lorok Semarang. Perilaku Buang Air Besar Sembarangan (BABS) dan cenderung tidak memanfaatkan jamban yang dialami oleh warga di pemukiman pesisir merupakan salah satu kebiasaan yang dimiliki individu akibat dari meniru perilaku orang-orang disekitarnya.Karakteristik masyarakat Tambak Lorok yang tradisional serta memiliki latar belakang pendidikan yang rendah dan terbatasnya sosial ekonomi merupakan salah satu faktor penyebabnya.Hal ini juga merupakan karakteristik masyarakat Pulau Lipang yang sebagian besar memiliki mata pencaharian sebagai nelayan.

Waktu menggosok gigi terbanyak saat mandi pagi dan mandi sore sejumlah 36 responden (46.75\%). Data yang dirilis Departemen Kesehatan (Depkes) dari Riskesdas 2007 menunjukkan, karies gigi secara nasional adalah 4,85. Sebanyak $72,1 \%$ penduduk Indonesia mempunyai pengalaman karies dan 23,4\% penduduk indonesia mengeluhkan adanya masalah gigi dan mulutnya dan hanya $29,6 \%$ yang mencari pertolongan dan mendapatkan perawatan dari tenaga kesehatan. Untuk umur 5-14 tahun prevalensi masalah kesehatan gigi dan mulut mencapai 42,2\% dan sebanyak $57,5 \%$ yang menerima perawatan atau pengobatan gigi dari tenaga kesehatan gigi. Penduduk Indonesia usia 10 tahun ke atas telah melakukan sikat gigi setiap hari $91,1 \%$, namun hanya $7,3 \%$ telah menggosok gigi dua kali di waktu yang benar, yaitu pagi hari dan malam sebelum tidur.

Merokok dalam keluarga ada 24 keluarga (31.17\%).Prevalensi perokok di Indonesia terus mengalami peningkatan dari tahun ke tahun. Jumlah perokok pria meningkat $14 \%$, sedangkan perokok wanita meningkat sebanyak 2,8\% dari tahun 1995 sampai tahun 2011. Pada tahun 1995 jumlah perokok pria di Indonesia sebanyak $53,4 \%$ sedangkan tahun 2011 menjadi 67,4\%. Untuk perokok wanita meningkat dari $1,7 \%$ pada tahun 1995 menjadi $67,4 \%$ pada tahun 2011 (Aliansi Pengendalian Tembakau Indonesia, 2013). Data dari GATS tahun 2011 menyebutkan bahwa Indonesia merupakan negara ketiga dengan jumlah perokok tertinggi di dunia setelah Cina dan India dengan prevalensi perokok sebanyak 36,1\% (Aliansi Pengendalian Tembakau Indonesia, 2013). Rokok adalah silinder dari kertas berukuran panjang antara 70 hingga $120 \mathrm{~mm}$ dengan diameter sekitar 10 $\mathrm{mm}$ yang berisi daun-daun tembakau yang telah di cacah (Jaya, 2009).Rokok merupakan salah satu produk industri dan komoditi internasional yang mengandung sekitar 300 bahan kimiawi. Unsur-unsur 
yang penting antara lain : tar, nikotin, benzovrin, metal-kloride, aseton, amonia, dan karbon monoksida (Bustan, 2007). Selain itu sebatang rokok mengandung 4.000 jenis senyawa kimia beracun yang berbahaya untuk tubuh dimana 43 diantaranya bersifat karsinogenik (Aditama, 2013).Dengan komponen utama adalah nikotin suatu zat berbahaya penyebab kecanduan, tar yang bersifat karsinogenik, dan CO yang dapat menurunkan kandungan oksigen dalam darah.Rokok juga dapat menimbulkan penyakit seperti jantung koroner, stroke dan kanker. Sukendro (2007) menyatakan asap rokok mengandung ribuan bahan kimia beracun dan bahan-bahan yang dapat menimbulkan kanker. Rokok juga dapat menyebabkan iritasi pada mata, hidung, tenggorokan, menstimulasi kambuhnya penyakit asma, kanker paru, gangguan pernapasan, dan batuk yang menghasilkan dahak (Istiqomah, 2003). Bahkan di Amerika, rokok dapat menyebabkan kematian lebih dari 400.000 orang, namun demikian setiap hari lebih dari 3000 anak dan remaja menjadi perokok (Surani, 2011). WHO memperkirakan separuh kematian di Asia dikarenakan tingginya peningkatan penggunaan tembakau.Angka kematian akibat rokok di negara berkembang meningkat hampir 4 kali lipat. Pada tahun 2000 jumlah kematian akibat rokok sebesar 2,1 juta dan pada tahun 2030 diperkirakan menjadi 6,4 juta jiwa. Sedangkan di negara maju kematian akibat rokok justru mengalami penurunan, yaitu dari 2,8 juta pada tahun 2000 menjadi 1,6 juta jiwa pada tahun 2030 (Aliansi Pengendalian Tembakau Indonesia, 2013).

Keluarga yang mengonsumsi alcohol berjumlah 70 keluarga $(90.91 \%)$. Hasil penelitian ini sesuai dengan hasil penelitian yang dilakukan oleh Riskiyani tentang aspek social budaya pada konsumsi minuman beralkohol (Tuak) di Kabupaten Toraja Utara bahwa informan memahami tuak sebagai minuman tradisional beralkohol yang memiliki pengaruh positif dan negatif bagi pengonsumsinya. Kebanyakan dari mereka mengonsumsi karena lingkungan sosialnya. Dari aspek budaya, tuak merupakan minuman yang dapat mempererat persaudaraan dan selalu disajikan dalam perayaan pesta adat. Penelitian ini menyimpulkan bahwa konsumsi tuak di Toraja Utara merupakan bagian daripada tradisi masyarakat, baik pada perayaan pesta adat maupun dikegiatan seharihari.

\section{KESIMPULAN}

Kesimpulan penelitian tentang Derajat Kesehatan Masyarakat di Pulau Lipang Kecamatan Kendahe Kabupaten Kepulauan Sangihe menunjukkan bahwa menunjukkan bahwa indicator mortalitas Diabetes Melitus per-1000 penduduk adalah 40\%, indicator morbiditas malaria per-1000 penduduk adalah $77,78 \%$, indicator morbiditas penyakit jantung adalah 31,03\%. Indeks Fertilitas ibu hamil $8 \%$ dan Balita $17 \%$.

\section{DAFTAR RUJUKAN}

Anwar, A.Muhamad S. 2016. Derajat Kesehatan Masyarakat Kepualuan di Kecamatan Kepulauan Derawan Kabpuaten Berau. ISSN 2443-1141

Amanda, Imalia.2009. Hubungan antara pendiidkan, pendapatan, dan Perilaku Hidup Bersih dan Sehat (PHBS) pada pedangang Hidangan Istimewa Kampung (HIK) di Pasar Kliwon dan Jebres Kota Surakarta .

Aprilianti.2009. Hubungan Pengetahuan dengan Perilaku Hidup Bersih dan Sehat Masyarakat.Grahacendekia. Wordpress.com diakses tanggal 10 Jnauari 2016

Ambarwati. 2014. Media leaflet, video, pengetahuan siswa SD tentang Bahaya Merokok, Jurnal Kesehatan

Masyarakat.http;//journal.unnes.ac.id

Anuar Chairil.2015. Analisis kualitas air hujan sebagai sumber air minum terhadap kesehatan masyarakat Studi kasus di Kecamatan Bangko Bagansiapiapi. Jurnal Dinamika Lingkungan Indonesia Vol.2 Nomor 1 ISSN 2356-2226 
Arikunto,S.2016. Prosedur Penelitian Suatu pendekatan Praktik Edisi Revisi V.jakarta : Rineka Cipta

Asmaripa,A.2010. Desa Siaga dan manajemen Kesehatan Bencana Vol. 1 No.01

Adnani,H.2016. Buku Ajar Ilmu kesehatan Masyarakat. Nuha Medika. Yokyakarta

Besajja, A. 2013. Indikator Kesehatan Masyarakat dan rencana strategi http://adibesajja.blogspot.com/2013/02/indikat or-kesehatan-masyarakat.dan.html diakses tanggal 27 April 2019

Departemen Kesehatan RI pusat Promosi Kesehatan.2009. Panduan Peningkatan Perilaku Hidup Bersih Sehat Rumah tangga

Dian Kartika, 2016. Pelayanan Kesehatan Tradisional dan Perlindungan hokum bagi Pasien. SOEPRA Jurnal Hukum Kesehatan Vol.2 No.1
Hidayat, Aziz Alimul. 2007. Metode Penelitian Teknik Analisa Data. Jakarta: salemba Medika

Surnatiningsih,A. 2015. Pemberdayaan Masyarakat Desa. Universitas Gadjah Mada Yokyakrata

Kurniawati, Linda Destiya.2017. Faktor-faktor yang berpengaruh terhadap perilaku kepada keluarga dalam pemanfaatan Jamban di Pemukiman Kampung Nelayan Tambak Lorok Semarang. Public Health Perspective Journal 2 (1)

Pranata, Jevry.2012. Gambaran Perilaku Pemnafaatan Ventilasi, penutupan penampungan air pengurasan bak mandi untuk mencegah kejadian demam berdarah di Wilayah Puskesmas Pajang Surakarta

Undang-Undang Nomor 40 tahun 2004 dan Undangundang Nomor 24 tahun 2011. 